\title{
Congenital factor VII deficiency
}

INSERM

\section{Source}

INSERM. (1999). Orphanet: an online rare disease and orphan drug data base. Congenital factor VII deficiency. ORPHA:327

A rare, genetic, congenital vitamin K-dependant coagulation factor deficiency disorder characterized by decreased levels or absence of coagulation factor VII (FVII), resulting in bleeding diathesis of variable severity. 